\title{
Nanostructured Tin Oxide Films: Physical Synthesis, Characterization, and Gas Sensing Properties
}

\author{
S. M. Ingole ${ }^{a}$, S. T. Navale ${ }^{b}$, Y. H. Navale ${ }^{a}$, D. K. Bandgar ${ }^{a}$, F. J. Stadler ${ }^{b}$, R. S. Mane ${ }^{e}$, \\ N. S. Ramgir ${ }^{c}$, S. K. Gupta ${ }^{c}$, D. K. Aswal ${ }^{d}$, V.B. Patil ${ }^{a} *$ \\ ${ }^{a}$ Functional Materials Research Laboratory, School of Physical Sciences, Solapur University, \\ Solapur-413255, (MS) India (*Email. drvbpatil@ gmailcom) \\ ${ }^{b}$ College of Materials Science and Engineering, Shenzhen Key Laboratory of Polymer Science \\ and Technology, Shenzhen University, Shenzhen 518060, P. R. China \\ ${ }^{c}$ Technical Physics Division, Bhabha Atomic Research Centre, Trombay, Mumbai, India. \\ ${ }^{d}$ National Physical Laboratory, New Delhi, India. \\ ${ }^{e}$ School of Physical Sciences, SRTM University, Nanded, (MS), India.
}

\begin{abstract}
Nanostructured tin oxide $\left(\mathrm{SnO}_{2}\right)$ films are synthesized using physical method i.e. thermal evaporation and are further characterized with X-ray diffraction, X-ray photoelectron spectroscopy, scanning electron microscopy, transmission electron microscopy, and atomic force microscopy measurement techniques for confirming its structure and morphology. The chemiresistive properties of $\mathrm{SnO}_{2}$ films are studied towards different oxidizing and reducing gases where these films have demonstrated considerable selectivity towards oxidizing nitrogen dioxide $\left(\mathrm{NO}_{2}\right)$ gas with a maximum response of $403 \%$ to $100 \mathrm{ppm} @ 200^{\circ} \mathrm{C}$, and fast response and recovery times of $4 \mathrm{~s}$ and $210 \mathrm{~s}$, respectively, than other test gases. In addition, $\mathrm{SnO}_{2}$ films are enabling to detect as low as 1 ppm $\mathrm{NO}_{2}$ gas concentration @ 200 $\mathrm{C}$ with $23 \%$ response enhancement. Chemiresistive performances of $\mathrm{SnO}_{2}$ films are carried out in the range of 1-100 ppm and reported. Finally, plausible adsorption and desorption reaction mechanism of $\mathrm{NO}_{2}$ gas molecules with $\mathrm{SnO}_{2}$ film surface has been thoroughly discussed by means of an impedance spectroscopy analysis.
\end{abstract}

Keywords: Thermal evaporation; Tin oxide, Structure and morphology; $\mathrm{NO}_{2}$ sensor; Impedance spectroscopy. 


\section{Introduction}

Field of gas sensors is increasing extensively in which the use of metal oxide semiconductors is unavoidable [1-3]. These gas sensors have undergone trough various developments as they demonstrate an inadequate sensing performance in terms of selectivity, sensitivity, stability, response time, and cost [1-4]. Sensors based on metal oxide usually reveal high response at working temperatures above $300^{\circ} \mathrm{C}$ [4-6]. Basically, an ideal sensor material must be responsive at lower operating temperatures and should have high selectivity towards target gas. The process of gas sensing mainly includes three steps; first one is the dynamic process of adsorption and/or reactions of gases on the sensor surface, second one is the accumulation or depletion process of surface charges by the adsorbents, and third is the change of electrical resistance of the sensing material which is an indicator of the gas sensing activity [7]. The density of adsorbents depends on the surface temperature [8]. Solid state gas sensors are extensively useful in detecting toxic, harmful, and combustible gases of various concentrations [9-11], which are classified according to their sensing mechanism types such as semiconductor gas sensors, solid electrolyte gas sensors, and catalytic combustion gas sensors etc. [12]. Out of these sensors, metal oxide semiconductor-based gas sensors have broadly been used in numerous applications such as domestic security and safety, environmental monitoring, health care, defense, food industry, and medical [13-15]. Metal oxides like titanium oxide, tin oxide $\left(\mathrm{SnO}_{2}\right)$, zinc oxide, tungsten oxide, indium oxide, and copper oxide have extensively been envisaged in gas sensing application [16-18]. Among the variety of metal oxides, $\mathrm{SnO}_{2}$ is one of the most popular materials so far envisaged in gas sensing application owing to its high crystallinity, tunable morphology, and chemical/thermal stability. So far, $\mathrm{SnO}_{2}$-based gas sensors are being employed for sensing of different gas species such as nitrogen dioxide $\left(\mathrm{NO}_{2}\right)$, hydrogen sulfide $\left(\mathrm{H}_{2} \mathrm{~S}\right)$, ethanol $\left(\mathrm{C}_{2} \mathrm{H}_{5} \mathrm{OH}\right)$, carbon monoxide $(\mathrm{CO})$, and methanol $\left(\mathrm{CH}_{3} \mathrm{OH}\right)$ [19-23]. Out of these gases, $\mathrm{NO}_{2}$ is highly reactive oxidant, toxic, and corrosive gas can be produced from the combustion of engine and thermal power station sources. The $\mathrm{NO}_{2}$ gas causes respiratory system and an impairing in the lung function with long-term exposure [24, 25]. Therefore, it is a need to develop a highly sensitive gas sensor for easily detecting $\mathrm{NO}_{2}$ gas at it's an early stage.

As far as synthesis of $\mathrm{SnO}_{2}$ concern, several physical and chemical methods such as hydrothermal [26], sol-gel [27], ultrasonic spray pyrolysis [28], chemical vapor deposition [29], pulsed laser deposition [30], sputtering [31], and thermal evaporation etc., have been used in 
literature $[32,33]$. Thermal evaporation (efficient and cost-effective physical synthesis route) is simple, flexible, and effective in producing nanoparticles (NPs) of various dimensions. As per the literature survey, it is inferred that little efforts have been attempted in preparing $\mathrm{SnO}_{2} \mathrm{NPs}$ by thermal evaporation method. There are few reports where semiconducting metal oxide thin films of pure and modified $\mathrm{SnO}_{2}$ with suitable catalysts are used for the detection of $\mathrm{NO}_{2}$ gas. The reported operating temperatures and detection limits of $\mathrm{NO}_{2}$ are quite high [34-45].

In the present work, we report on the synthesis of $\mathrm{SnO}_{2}$ films by thermal evaporation method without the use of any catalyst, which when used in sensor application reveals an enhanced response to $\mathrm{NO}_{2}$. An improved rate of adsorption and desorption of target gas on the sensor surface is evidenced. The as-synthesized $\mathrm{SnO}_{2}$ films are characterized by X-ray powder diffraction (XRD), X-ray photoelectron spectroscopy (XPS), scanning electron microscope (SEM), energy dispersive X-ray analysis (EDAX), atomic force microscopy (AFM), transmission electron microscopy (TEM), and contact angle (CA) measurement techniques. The responses of $\mathrm{SnO}_{2}$ film towards $\mathrm{NO}_{2}, \mathrm{Cl}_{2}, \mathrm{H}_{2} \mathrm{~S}, \mathrm{CH}_{3} \mathrm{OH}$, and $\mathrm{NH}_{3}$ gases were tested for different operating temperatures and reported herein. The gas sensing parameters, of $\mathrm{SnO}_{2}$ film with other gases, such as gas selectivity, response, reproducibility, and stability are systematically studied and reported. An interaction of $\mathrm{NO}_{2}$ gas molecules with $\mathrm{SnO}_{2} \mathrm{NPs}$ film surface is explained on the basis of impedance spectroscopy results.

\section{Experimental details}

The $\mathrm{SnO}_{2}$ films, composed of NPs, were prepared by high vacuum thermal coating unit (IHVU) onto the glass substrates. For synthesis of $\mathrm{SnO}_{2}$ films, highly pure $\mathrm{Sn}$ powder (99.99\% Aldrich) was used as source material, which poured in molybdenum boat and placed in a vacuum chamber connected to a high voltage power supply. The pre-cleaned glass substrate was fixed to substrate holder displayed in schematic diagram of thermal evaporation in Fig. 1. The pressure maintained inside the chamber was $10^{-5} / 10^{-6}$ mbar and the current was allowed to increase to evaporate Sn-powder. The distance between source and substrate was kept $15 \mathrm{~cm}$. Finally, the deposited film was annealed at $700^{\circ} \mathrm{C}$ for $20 \mathrm{~min}$ in presence of ambient air in the zone furnace.

The crystalline structure and morphology of $\mathrm{SnO}_{2}$ film was examined by $\mathrm{X}$-ray diffractometer (XRD, Rigaku, Ultima IV, Cu Ka/40 kV/40 mA, $\lambda=1.5406$ A, scan range 10$80^{\circ}$ ), scanning electron microscopy (SEM, Model: JEOL-6300F), and transmission electron microscopy (TEM, Model: FEI TECNAI G2 S-TWIN instruments). Elemental analysis was 
carried out using X-ray photoelectron spectroscopy (XPS, VG, Multilab 2000). The 2D and 3D atomic force microscopy (AFM) images of $\mathrm{SnO}_{2}$ films were obtained to investigate the surface roughness. The surface wetting test was performed with Rame-Hart USA water contact angle measurement unit equipment with CCD camera. Wayne Kerr precision impedance analyzer (model: $6500 \mathrm{~B}$ ) in the frequency range of $20 \mathrm{~Hz}-10 \mathrm{MHz}$ was used for impedance measurement. Gas sensing tests were performed on in-house fabricated high temperature gas sensing measurement unit [46]. The gas response of $\mathrm{SnO}_{2}$ film is evaluated by following relation:

$$
\text { Response }(S \%)=\frac{\left|R_{\text {air }}-R_{\text {gas }}\right|}{R_{\text {air }}} \times 100
$$

where $\mathrm{R}_{\mathrm{air}}$ and $\mathrm{R}_{\mathrm{gas}}$ are the resistances of sensor in presence of air and $\mathrm{NO}_{2}$ gas, respectively.

\section{Results and discussion}

\subsection{Structural analysis}

The XRD pattern of $\mathrm{SnO}_{2}$ film, grown at $700^{\circ} \mathrm{C}$ (Fig. 2(a)), shows the number of welldefined diffraction peaks, which are indexed to the tetragonal rutile structure of $\mathrm{SnO}_{2}$ [JCPDS file no. 41-1445]. No other peaks of impurities are detected in XRD pattern suggesting the high purity of the as-deposited $\mathrm{SnO}_{2}$ product. The comparison of standard and observed $2 \theta$, interplanar spacing $(d)$, and intensity $\left(I / I_{\max }\right)$ values with respect to their $h k l$ planes of $\mathrm{SnO}_{2}$ are given in Table 1, suggesting obtained ' $d$ ' values are in good agreement with standard ' $d$ ' values. The lattice parameters are obtained from following relation;

$$
\frac{1}{d^{2}}=\frac{h^{2}+k^{2}}{a^{2}}+\frac{l^{2}}{c^{2}}
$$

The calculated lattice parameters, $a=b=4.73$ and $c=3.18 \AA$, of tetragonal $\mathrm{SnO}_{2}$ are in good agreement with the JCPDS file no. 41-1445. The average crystallite size, calculate along (110) plane using Scherrer relation, is found to be $\approx 30 \mathrm{~nm}$. The various structural parameters, shown in Table 2, like micro-strain $(\varepsilon)$, dislocation density $(\rho)$, and stacking fault $(S F)$ of prepared $\mathrm{SnO}_{2}$ film have been calculated using $\varepsilon=(\beta \cos \theta) / 4, \rho=1 / \mathrm{D}^{2}$, and $\mathrm{SF}=\left(2 \pi^{2} / 45(3 \tan \theta)^{1 / 2}\right)$ relations [47]. The obtained $\varepsilon$ and $S F$ values for $\mathrm{SnO}_{2}$ film are smaller, suggesting the presence of lattice imperfections and defects in as-prepared film [48]. The amount of defects in the crystal can be measured by $\rho$ and smaller value of $\rho$ obtained in the present study is supporting for the good crystallinity of $\mathrm{SnO}_{2}$ film prepared using the thermal evaporation process. 


\subsection{Elemental analysis}

The wide region XPS survey spectrum of $\mathrm{SnO}_{2}$ is shown in Fig. 2 (b), from which peaks for $\mathrm{Sn}$ and $\mathrm{O}$ elements are clearly seen. The low resolution XPS spectrum can be used to measure the binding energy range. High resolution Sn-3d and O1s core level XPS spectrums are given in Fig. 2(c) \& (d), respectively. The binding energy peaks (Fig. 2(c)) at $485.36 \mathrm{eV}$ and $495.2 \mathrm{eV}$ are due to the spin-orbit of $\mathrm{Sn}-3 \mathrm{~d}_{5 / 2}$ and $\mathrm{Sn}-3 \mathrm{~d}_{3 / 2}$, matching strongly with previously reported values [49]. The peak centered at $529.2 \mathrm{eV}$ (Fig. 2 (d)) indicates the existence of oxygen [50]. Thus, XPS analysis, in addition to XRD measurement, corroborates the formation of $\mathrm{SnO}_{2}$.

\subsection{Morphological analysis}

The SEM images of $a s$-synthesized $\mathrm{SnO}_{2}$ film (Fig. 3(a)) present uniformly distributed and interconnected globules which are composed of large number of NPs. Few voids are seen between them. Such kind of morphology can be beneficial for gas sensing application as it may support for the adsorption of gas molecules on the surface of film [51]. The elemental composition present in the as-synthesized $\mathrm{SnO}_{2}$ film examined by EDAX spectrum (shown in Fig.3 (b)), which confirms the presence of Sn and $\mathrm{O}$ elements without any other noticeable impurity. The elements present and their respective weight percentages of $\mathrm{SnO}_{2}$ film are given in the inset of Table in Fig. 3(b). The 2D and 3D AFM micrographs of the $\mathrm{SnO}_{2}$ film are shown in Fig. 3(c) \& (d), respectively. The 2D AFM image of the film surface demonstrates the interconnected globules-type surface. Rough surface consisting of globules with a RMS roughness of $53.1 \mathrm{~nm}$ is evidenced from 3D AFM image. Interconnected NPs, with an average diameter of $27 \mathrm{~nm}$, are confirmed from the TEM image (Fig. 4(a)) analysis. The SAED pattern (Fig. 4(c)) is supporting for the polycrystalline nature and rutile phase of as-synthesized $\mathrm{SnO}_{2}$ as there are well-defined circular rings, instead of regular spots and cloudy fuzzy white background whose radii are closely matching to that of lattice spacing of XRD planes. The surface wettability test (water contact angle measurement) performed on $\mathrm{SnO}_{2}$ film surface, which correlates with the interfacial tensions i.e. water/air, water/solid, and solid/air. The ratio among these tensions determines the contact angle ' $\theta$ ' between the water droplet and the surface of $\mathrm{SnO}_{2}$ film. Less than $20^{\circ}$ water contact angle specifies entirely wetting behavior i.e. surface is hydrophilic, and on the other hand if water contact angle is more than $150^{\circ}$ signifies the surface is hydrophobic. From Fig. 4(c) it is clear that, the $\mathrm{SnO}_{2}$ film surface is hydrophilic, as the water contact angle is 
$81^{\circ}$ (less than $90^{\circ}$ ) which can be useful for building intimate contact of $\mathrm{SnO}_{2}$ surface when applied in gas sensing application.

\subsection{Gas sensing properties}

\subsubsection{Selectivity study}

Selectivity, the ability of a sensor to respond to a certain gas in presence of other test gases, is considered as essential parameter of chemiresistive type of sensors. Therefore, for the selectivity study, initially the sensing performance of $\mathrm{SnO}_{2}$ sensor film towards fixed $100 \mathrm{ppm}$ concentration of various oxidizing $\left(\mathrm{NO}_{2}\right.$ and $\left.\mathrm{Cl}_{2}\right)$ and reducing $\left(\mathrm{H}_{2} \mathrm{~S}, \mathrm{NH}_{3}\right.$, and $\left.\mathrm{CH}_{3} \mathrm{OH}\right)$ gases are tested and the subsequent results are presented in Fig. 5(a). The sensor film exhibits a high response of $403 \%$ to $\mathrm{NO}_{2}$ gas as compared to other target gases $\left(\mathrm{Cl}_{2}=88 \%, \mathrm{H}_{2} \mathrm{~S}=92 \%, \mathrm{NH}_{3}=\right.$ $7 \%$, and $\mathrm{CH}_{3} \mathrm{OH}=9 \%$ ) @ $200^{\circ} \mathrm{C}$, confirming the better selectivity of $\mathrm{SnO}_{2}$ film to $\mathrm{NO}_{2}$ gas than other gases. On exposure to oxidizing gases $\mathrm{SnO}_{2}$ film resistance is increased and for reducing gases it is decreased, suggesting an $n$-type conduction-behavior of $\mathrm{SnO}_{2}$. Furthermore, the selectivity coefficient $(K)$ is calculated using the relation,

$$
K=\frac{S_{A}}{S_{B}}
$$

where $\mathrm{S}_{\mathrm{A}}$ is the response of film to target gas (here $\mathrm{NO}_{2}$ ) and $\mathrm{S}_{\mathrm{B}}$ is the response of film to other gas. The calculated $K$ values are displayed in Table 3. Obtained higher $K$ value for a particular gas is nothing but a superior capability of sensor to distinguish the target gas from the mixture of gases [52]. In order to optimize the operating temperature of $\mathrm{SnO}_{2}$ sensor film, the gas sensing measurements were performed at different temperatures from 100 to $300^{\circ} \mathrm{C}$ (Fig.5 (b)), where the $\mathrm{SnO}_{2}$ film shows the higher response to $\mathrm{NO}_{2}$ gas @ $200^{\circ} \mathrm{C}$ than that of other operating temperatures. Therefore, for the rest of gas sensing measurement studies $200^{\circ} \mathrm{C}$ operating temperature of $\mathrm{SnO}_{2}$ film sensor is kept constant.

\subsubsection{Gas sensing mechanism}

The sensing mechanism of $\mathrm{SnO}_{2}$ film, in presence of air and $\mathrm{NO}_{2}$ gas, is shown in Fig.6 (a). When $\mathrm{NO}_{2}$ gas molecules adsorb on the surface of $\mathrm{SnO}_{2}$ film sensor then they interact directly with the accessible $\mathrm{Sn}$ sites and extract electrons from the conduction band of $\mathrm{SnO}_{2}$ by forming $\mathrm{NO}_{2}^{-}$. The interaction between the $\mathrm{NO}_{2}$ gas molecules and $\mathrm{SnO}_{2}$ takes place in the following ways [54],

$$
\mathrm{NO}_{2}+\mathrm{Sn}_{\stackrel{+2}{\text { adsorption }} \longrightarrow}^{\longrightarrow}\left(\mathrm{Sn}^{3+}-\mathrm{NO}_{2}^{-}\right) \stackrel{\text { desorption }}{\longrightarrow}\left(\mathrm{Sn}^{3+}-\mathrm{O}^{-}\right)+\mathrm{NO}
$$




$$
2\left(\mathrm{Sn}^{3+}-\mathrm{O}^{-}\right) \stackrel{\text { desorption }}{\longrightarrow} 2 \mathrm{Sn}^{+2}+\mathrm{O}_{2}
$$

The decrease in the concentration of electrons within the conduction band of $\mathrm{SnO}_{2}$ results into the increase of the sensor resistance $\left(\mathrm{R}_{\mathrm{g}}\right)$. As a result, change in electrical resistance helps to find response of $\mathrm{SnO}_{2}$ sensor (using equation 1). During the recovery time, these adsorbed $\mathrm{NO}_{2}{ }^{-}$ species desorbs as NO gas molecules by leaving chemisorbed oxygen species behind (Eq. (5)) on the surface of $\mathrm{SnO}_{2}$ film through the subsequent reaction:

$$
\mathrm{NO}_{2}^{-}{ }_{(\mathrm{ads}) .}+2 \mathrm{O}^{-}+\mathrm{e}^{-} \longrightarrow \mathrm{NO}_{(\mathrm{g})}+1 / 2 \mathrm{O}_{2(\mathrm{~g})}+2 \mathrm{O}^{2-}
$$

Afterward, the chemisorbed oxygen species on the $\mathrm{SnO}_{2}$ surface release $\mathrm{O}_{2}$ gas according to Eq. (6 \& 7). Thus, the resistance retains its original value $\left(R_{a}\right)$. From Fig. $6(b)$ it is observed that, in presence of $\mathrm{NO}_{2}$ gas, the resistance of $\mathrm{SnO}_{2}$ film sensor is increases rapidly with respect to time and a flat terrain region is achieved in a few seconds, signifying the fast response to $\mathrm{NO}_{2}$ gas. For the recovery of the sensor, on opening outlet of the chamber fresh air is allowed to pass in as a result $\mathrm{NO}_{2}$ molecules desorbs and the sensor once again regains at its initial value of resistance. Thermally activated electron transfers reaction and hence $\mathrm{SnO}_{2}$ shows fast recovery [55].

\subsubsection{Dynamic response of $\mathrm{SnO}_{2}$ sensor}

Fig. 7(a) shows the variation of response value of $\mathrm{SnO}_{2}$ film towards 1 and $100 \mathrm{ppm} \mathrm{NO}_{2}$ @ $200^{\circ} \mathrm{C}$, suggesting the $\mathrm{SnO}_{2}$ film exhibits $23 \%$ response to $1 \mathrm{ppm}$ and $403 \%$ to $100 \mathrm{ppm}$ of $\mathrm{NO}_{2}$. Fig. 7(b) shows the dynamic response curve of $\mathrm{SnO}_{2}$ sensor film as a function of time to 1100 ppm concentration levels of $\mathrm{NO}_{2}$ gas @ $200^{\circ} \mathrm{C}$, where the response values are increased with increasing $\mathrm{NO}_{2}$ concentration. The response values, calculated using eq ${ }^{\mathrm{n}}(1)$, of $\mathrm{SnO}_{2}$ film at 1, 5, $10,20,40,60,80$, and 100 ppm levels of $\mathrm{NO}_{2}$ gas are 23, 31, 112, 176, 234, 336, 352, and 403 $\%$, respectively. With increase in $\mathrm{NO}_{2}$ gas concentration the response of sensor is increased which can be explained on the basis of surface area and the number of available active sites of the sensor film. At higher $\mathrm{NO}_{2}$ gas concentration (herein $100 \mathrm{ppm}$ ), gas molecules cover excess surface area and there can be several reactions due to availability of more active sites on $\mathrm{SnO}_{2}$ sensor surface. On the other hand, at low concentration (herein $1 \mathrm{ppm}$ ) gas molecules cover limited surface area due to which few surface reactions are possible on $\mathrm{SnO}_{2}$ sensor surface and thereby, sensor demonstrates lower response [53].

\subsubsection{Response and recovery time values}

Response and recovery times are considered as key parameters for the practical sensor application. The time required for sensor to attain $90 \%$ of the maximum increase in resistance on 
exposure of target gas is referred as response time and the recovery time is the time to recover 90\% of the maximum resistance when sensor exposed to fresh air. The response and recovery times for $\mathrm{SnO}_{2}$ sensor to diverse concentrations of $\mathrm{NO}_{2}$ are calculated from the response curve (Fig. 7(b)) and are presented in Table 5. The response time values are decreased from $10 \mathrm{~s}$ to $4 \mathrm{~s}$ and recovery time value are increased from $123 \mathrm{~s}$ to $210 \mathrm{~s}$ with increase of $\mathrm{NO}_{2}$ gas concentration from 1 to $100 \mathrm{ppm}$. The decrease in response time is attributed to the availability of vacant sites on $\mathrm{SnO}_{2}$ sensor films for adsorption of gas. The behavior of increasing recovery time with increasing $\mathrm{NO}_{2}$ concentration is due to gas reaction species which residual after gas interaction resulting in decrease in desorption rate [56]. The comparison report with different sensing parameters of $\mathrm{SnO}_{2}$ sensor film, synthesized by thermal evaporation route, is tabulated in Table 4.

\subsubsection{Reproducibility and stability studies}

Fig. 7(c) shows that the repetitive electrical response for $\mathrm{SnO}_{2}$ film sensor upon exposure of $100 \mathrm{ppm} \mathrm{NO}_{2}$ gas. An identical response value upon repeating $100 \mathrm{ppm} \mathrm{NO}_{2}$ gas concentration is confirming the superb repeatability of the $\mathrm{SnO}_{2}$ sensor film. Fig. 7(d) shows the stability study of $\mathrm{SnO}_{2}$ sensor film to fixed 100 ppm of $\mathrm{NO}_{2}$ gas @ $200^{\circ} \mathrm{C}$ for a period of 60 days. Primarily, $\mathrm{SnO}_{2}$ sensor film demonstrates the maximum response of $403 \%$ and after 30 days which drops to $251 \%$ with stability of $62 \%$. After 30 days, the response value of $\mathrm{SnO}_{2}$ is nearly identical. This decrease in the response of $\mathrm{SnO}_{2}$ sensor is due to aging effect [57]. Gas sensing results reveal that the $\mathrm{SnO}_{2}$ sensor films, prepared by thermal deposition method, are reasonably sensitive to $\mathrm{NO}_{2}$ gas as linear variation in response between 1-100 ppm of $\mathrm{NO}_{2}$ with very fast response and recovery times, an excellent reproducibility in response value, and long term stability, are evidenced. These properties make it as a potential candidate for the detection of $\mathrm{NO}_{2}$ gas at its initial stage.

\subsection{Impedance Spectroscopy of $\mathrm{SnO}_{2}$ film}

The impedance measurement on $\mathrm{SnO}_{2}$ sensor film was carried out before and after exposure of $\mathrm{NO}_{2}$ gas in the frequency range of $20 \mathrm{~Hz}$ to $10 \mathrm{MHz}$ and the subsequent results are presented in Fig. (8). Plot of imaginary component $\left(Z^{\prime \prime}\right)$ against the real component $\left(Z^{\prime}\right)$ is a perfectly semicircle. The impedance spectrum of $\mathrm{SnO}_{2}$ film analyzed by means of the equivalent circuit is shown in inset of Fig. 8(a) where $R_{o}$ is in series with two RC networks $\left(R_{0}\right.$-frequency independent resistance, $\mathrm{C}_{\mathrm{b}}$-bulk capacitance, $\mathrm{R}_{\mathrm{b}}$-bulk resistance, $\mathrm{C}_{\mathrm{g}}$-grain boundary capacitance, 
and $\mathrm{R}_{\mathrm{g}}$-grain boundary resistance) [57]. The values of impedance parameters obtained from impedance spectra are tabulated in Table 5. There is very good agreement between the experimental data and simulated data (shown by solid red lines in Fig. 8(a)) is observed. On exposure to $100 \mathrm{ppm} \mathrm{NO} \mathrm{N}_{2}$ gas, both $\mathrm{C}_{\mathrm{b}}$ and $\mathrm{C}_{\mathrm{g}}$ values are decreased while $\mathrm{R}_{\mathrm{b}}$ and $\mathrm{R}_{\mathrm{g}}$ are increased. The change in the values of resistance and capacitance due to the interaction of $\mathrm{NO}_{2}$ gas is due to; $\mathrm{SnO}_{2}$ grains contain considerable fraction of $\mathrm{O}^{2-}$ adsorbates at grain boundaries which catch electrons from the grains of $\mathrm{SnO}_{2}$ and results in decreasing carrier density and conductivity. On the interaction of $\mathrm{SnO}_{2}$ film with oxidizing $\mathrm{NO}_{2}$ gas, adsorbed oxygen on the grain boundary of the $\mathrm{SnO}_{2}$ film can be replaced by gaseous species, as a result due to electron withdrawing nature of $\mathrm{NO}_{2}$ the resistance of $\mathrm{SnO}_{2}$ film is increased. Such an increase in resistance on $\mathrm{NO}_{2}$ exposure is mainly contributed by the grain boundaries of the $\mathrm{SnO}_{2}$ film.

Finally, we have compared the obtained gas sensing results with some of the reports ( $\mathrm{NO}_{2}$ entirely) on semiconducting $\mathrm{SnO}_{2}$ and $\mathrm{SnO}_{2}$ modified with suitable catalysts and the resulting comparison is tabulated in table 3 . The $\mathrm{SnO}_{2}$ films synthesized in present study exhibits good gas sensing properties (based on the comparison in table 3), in terms of lower operating temperature, fast response/recovery times, and lower detection limit, than previous reports.

\section{Conclusions}

Nanostructured $\mathrm{SnO}_{2}$ films are synthesized onto a glass substrate via inexpensive thermal evaporation method and their gas sensing properties were carried out towards host of gases such as $\mathrm{NO}_{2}, \mathrm{Cl}_{2}, \mathrm{H}_{2} \mathrm{~S}, \mathrm{CH}_{3} \mathrm{OH}$, and $\mathrm{NH}_{3}$. The $\mathrm{SnO}_{2}$ films found quite sensitive to $\mathrm{NO}_{2}$ gas @ $200^{\circ} \mathrm{C}$ with a maximum response of $403 \%\left(100 \mathrm{ppm} \mathrm{NO}\right.$ ). Moreover, the $\mathrm{SnO}_{2}$ film sensor detects as low as $1 \mathrm{ppm}$ of $\mathrm{NO}_{2}$ with $23 \%$ response value. Impedance spectroscopy analysis is used to study the interaction between $\mathrm{SnO}_{2}$ film and $\mathrm{NO}_{2}$ gas as well as to calculate the impedance parameters such as bulk and grain boundary resistance and capacitance. Based on the gas sensing results, it is concluded that the nanostructured $\mathrm{SnO}_{2}$ sensor film demonstrates high response, excellent selectivity, lower detection limit, good reproducibility and stability to $\mathrm{NO}_{2}$ gas @ $200^{\circ}$ C. 


\section{Acknowledgements}

Prof. V. B. Patil would like thank to DAE-BRNS, for financial support through the scheme no. 34/14/21/2015-BRNS and RUSA for financial support through the scheme no. RUSA/R\& I / 2016-17/267. FJS would like to thank National Science Foundation of China (21574086), Nanshan District Key Lab for Biopolymers and Safety Evaluation (No. KC2014ZDZJ0001A), Shenzhen Sci \& Tech research grant (ZDSYS201507141105130), and Shenzhen City Science and Technology Plan Project (JCYJ20140509172719311) for financial support

\section{References}

[1] S. Gubbala, V. Chakrapani, V. Kumar, M. K. Sunkara, "Band-Edge Engineered Hybrid Structures for Dye-Sensitized Solar Cells Based on $\mathrm{SnO}_{2}$ Nanowires” Adv. Funct. Mater., 18 (2008) 2411-2418.

[2] S.T. Navale, D.K. Bandgar, S.R. Nalage, G.D. Khuspe, M.A. Chougule, Y.D. Kolekar, Shashwati Sen, V.B. Patil, Synthesis of $\mathrm{Fe}_{2} \mathrm{O}_{3}$ nanoparticles for nitrogen dioxide gas sensing applications, Cera. Inter., 39 (2013) 6453-6460

[3] H. Meixner, U. Lampe, “Metal Oxide Sensors," Sens. Actua. B, 33 (1996) 198-202.

[4] Q Zhao, Y. Gao, X. Bai, C.Wu, Y. Xie, “Facile Synthesis of $\mathrm{SnO}_{2}$ Hollow Nanospheres and Applications in Gas Sensors and Electrocatalysts”, Eur. J. Inorg. Chem., (2006) 1643-1648.

[5] M. Batzill, "Surface Science Studies of Gas Sensing Materials: $\mathrm{SnO}_{2}$ ”, Sensors, 6 (2006) 1345-1366.

[6] A. Gurlo, "Nanosensors: Towards Morphological Control of Gas Sensing Activity $\mathrm{SnO}_{2}$, $\mathrm{In}_{2} \mathrm{O}_{3}, \mathrm{ZnO}$ and $\mathrm{WO}_{3}$ Case Studies", Nanoscale, 3 (2011) 154-165.

[7] Sunglyul Maeng, Sang-Woo Kim, Deuk-Hee Lee, Seung-Eon Moon, Ki-Chul Kim and Amitesh Maiti, " $\mathrm{SnO}_{2}$ Nano slab as $\mathrm{NO}_{2}$ Sensor: Identification of the $\mathrm{NO}_{2}$ Sensing Mechanism on $\mathrm{SnO}_{2}$ Surface”, ACS Appl. Mater. Interfaces, 6 (2014) 357-363.

[8] E. Comini, G.Vuidi, C, Malagu, G, Martinelli, Z, Pan, G, Sberveglieri, Z. L. Wang, "Electrical Properties of Tin Dioxide Two-Dimensional Nanostructures”, J. Phys. Chem. B, 108 (2004) 1882-1887.

[9] G. Sberveglieri, "Recent developments in semiconducting thin-film gas sensors", Sens. Actua. B, 23 (1995) 103-109.

[10] N. Yamazoe, N. Miura, “Environmental gas sensing.” Sens. Actuators B, 20 (1994) 95-102. 
[11] S.T. Navale, V.V. Jadhav, K. K. Tehare, R.U. R. Sagar, C. S. Biswas, M. Galluzzi, W. Liang, V. B. Patil , R. S. Mane, F. J. Stadler, Solid-state synthesis strategy of ZnO nanoparticles for the rapid detection of hazardous $\mathrm{Cl}_{2}$, Sens. Actua. B, 238 (2017) 11021110.

[12] A. Azad, S. Akbar, S. Mhaisalkar, L. Birkefeld, K. Goto, "Solid-state gas sensors: A review.” J. Electrochem. Soc., 139 (1992) 3690-3704.

[13] Q. Wan, Q. Li, Y. Chen, T. Wang, X. He, J. Li, C. Lin, "Fabrication and ethanol sensing characteristics of ZnO nanowire gas sensors”, Appl. Phys. Lett,. 84 (2004) 3654-3656.

[14] N. Yamazoe, N. Miura, "Environmental Gas Sensing”, Sens. Actua. B Chem., 20 (1994) 95-102.

[15] G. F. Fine, L. M. Cavanagh, A. Afonja, R. Binions, "Metal Oxide Semi-Conductor Gas Sensors in Environmental Monitoring”, Sensors, 106 (2010) 5469-5502.

[16] M. M. Arafat, B. Dinan, S. A. Akbar, A. Haseeb, "Gas sensors based on one dimensional nanostructured metal-oxides", A review, Sensors, 12 (2012) 7207-7258.

[17] G.N. Dar, A. Umar, S.A. Zaidi, S. Baskuotas, S.W. Hwang, M. Abaker, A. Al-Hajry, S.A. Al-Sayari, "Ultra-high sensitive ammonia chemical sensor based on $\mathrm{ZnO}$ nanopencils", Talanta, 89 (2012) 155-161.

[18] A. A. Ibrahim, G.N. Dar, S. A. Zaidi, A. Umar, M. Abaker, H. Bouzid, S. Baskoutas, "Growthand properties of Ag-doped $\mathrm{ZnO}$ nanoflowers for highly sensitive phenyl hydrazine chemical sensor application”, Talanta, 93 (2012) 257-263.

[19] G.D. Khuspe, R.D. Sakhare, S.T. Navale, M.A. Chougule, Y.D. Kolekar, R. N. Mulik, R.C. Pawar, C. S. Lee, V.B. Patil, "Nanostructured $\mathrm{SnO}_{2}$ thin films for $\mathrm{NO}_{2}$ gas sensing applications", Cera. Inter., 139 (2013) 8673-8679.

[20] J. Liu, W. Liu, Z. Yu, " $\mathrm{H}_{2} \mathrm{~S}$ detection sensing characteristic of $\mathrm{CuO} / \mathrm{SnO}_{2}$ sensor", Sensor, 3 (2003)110-118.

[21] W. Qin, L. Xu, J. Song, R. Xing, H. Song, "Highly Enhanced Gas Sensing Properties of Porous $\mathrm{SnO}_{2}-\mathrm{CeO}_{2}$ Composite Nanofibers Prepared by Electrospinning”, Sens. Actua. B, 185 (2013) 231-237.

[22] H. Huang, Y.C. Lee, O. K. Tan, W. Zhou, N. Peng, Q. Zhang, "High Sensitivity $\mathrm{SnO}_{2}$ Single Nanorod Sensors for the Detection of $\mathrm{H}_{2}$ Gas at Low Temperature", Nanotechnology, 20 (2009) 115501. 
[23] A. Kolmakov, Y. X. Zhang, G. S. Cheng, M. Moskovits, "Detection of CO and $\mathrm{O}_{2}$ Using Tin Oxide Nanowire Sensors”, Adv. Mater., 12 (2003) 997.

[24] S.T. Navale, D.K. Bandgar, M.A. Chougule, V. B. Patil, Facile method of preparation of $\mathrm{PbS}$ films for $\mathrm{NO}_{2}$ detection, RSC Adv., 5 (2015) 6518-6527.

[25] Bonn, Report on a WHO working group, health aspects of air pollution with particulate matter, ozone and nitrogen dioxide, World Health Organization, 2003, 1-92.

[26] B. Chen, J. M. Russell, W. Shi, L. Zhang, E. T. Samulski , "Large-Scale, solution phase growth of single-crystalline $\mathrm{SnO}_{2}$ nanorods", J . Am. Chem. Soc., 126 (2004) 5972-5973.

[27] L. Francioso, A. Forleo, S. Capone, M. Epifani, A. M. Taurino, P. Siciliano, "Nanostructured $\mathrm{In}_{2} \mathrm{O}_{3}-\mathrm{SnO}_{2}$ sol-gel thin film as material for $\mathrm{NO}_{2}$ detection", Sens. Actua. B, 114 (2006) 646-655.

[28] V. Bilgin, S. Kose, F. Atay, I. Akyuz, "The effect of Zn concentration on some physical properties of tin oxide films obtained by ultrasonic spray pyrolysis”, Mater. Lett., 58 (2004) 3686-3693.

[29] R.Y. Korotkov, P. Ricou, A.J.E. Farran, "Preferred orientations in polycrystalline $\mathrm{SnO}_{2}$ films grown by atmospheric pressure chemical vapor deposition", Thin Solid Films, 502 (2006) 79-87.

[30] A. M. Serventi, R. Dolbec, M. A. El Khakani, R.G. Saint-Jacques, D.G. Rickerby, "Highresolution transmission electron microscopy investigation of the nanostructure of undoped and Pt-doped nanocrystalline pulsed laser deposited $\mathrm{SnO}_{2}$ thin films", J. Phys. Chem. Solids, 64 (2003) 2097-2103.

[31] A.S. Reddy, N.M. Figueiredo, A. Cavaleiro, "Nanocrystalline Au: Ag: $\mathrm{SnO}_{2}$ films prepared by pulsed magnetron sputtering”, J. Phys. Chem. Solids, 74 (2013) 825-829.

[32] N. G Cho, D. J. Yang, M.-J. Jin, H.-G. Kim, H. L. Tuller, I.-D. Kim, "Highly Sensitive $\mathrm{SnO}_{2}$ Hollow Nanofiber Based $\mathrm{NO}_{2}$ Gas Sensor", Sens. Actua. B, 160 (2011) 1468-1472.

[33] J. Q. Hu, Y. Bando and D. Golberg, "Self-catalyst growth and optical properties of novel SnO2 fishbone-like nanoribbons”, Chem. Phys. Lett., 372 (2003) 758-762.

[34] J. Kaur, S.C. Roy, M.C. Bhatnagar, "Highly sensitive $\mathrm{SnO}_{2}$ thin film $\mathrm{NO}_{2}$ gas sensor operating at low temperature”, Sensors \& Actuators B, 123 (2007) 1090-1095. 
[35] L. Francioso, A. Forleo, S. Capone, M. Epifani, A.M. Taurino, P. Siciliano, Nanostructured $\mathrm{In}_{2} \mathrm{O}_{3}-\mathrm{SnO}_{2}$ sol-gel thin film as material for $\mathrm{NO}_{2}$ detection, Sens. Actua. B, 114 (2006) 646-655.

[36] C. Liangyuan, B. Shouli, Z. Guojun, L. Dianqing, C. Aifan, C.C. Liu, "Synthesis of ZnO$\mathrm{SnO}_{2}$ nanocomposites by microemulsion and sensing properties for $\mathrm{NO}_{2}$ ", Sens. Actua. B, 2008 (134) 360-366.

[37] Z. Ling, C. Leach, "The effect of relative humidity on the $\mathrm{NO}_{2}$ sensitivity of a $\mathrm{SnO}_{2} / \mathrm{WO}_{3}$ heterojunction gas sensor”, Sens. Actua. B, 2004 (102) 102-106.

[38] K.Y. Choi, J.S. Park, K.B. Park, H. Kim, H.D. Park, S.D. Kim, "Low power micro-gas sensors using mixed $\mathrm{SnO}_{2}$ nanoparticles and MWCNTs to detect $\mathrm{NO}_{2}, \mathrm{NH}_{3}$, and xylene gases for ubiquitous sensor network applications", Sens. Actua. B, 150 (2010) 65-72.

[39] E. Zampiceni, E. Comini, G. Faglia, G. Sberveglieri, S. Kaciulis, L. Pandolfi, S. Viticoli, "Composition influence on the properties of sputtered Sn-W-O films", Sens. Actua. B, 89 (2003) 225-231.

[40] P.G. Su, R. J. Wu, F.P. Nieh, "Detection of nitrogen dioxide using mixed tungsten oxidebased thick film semiconductor sensor", Talanta, 59 (2003) 667-672.

[41] B. Shouli, L. Dianqing, H. Dongmei, L. Ruixian, C. Aifan, C.C. Liu, "Preparation, characterization of $\mathrm{WO}_{3}-\mathrm{SnO}_{2}$ nanocomposites and their sensing properties for $\mathrm{NO}_{2}$ ", Sens. Actua. B, 150 (2010) 749-755.

[42] T. Hyodo, T. Mori, A. Kawahara, H. Katsuki, Y. Shimizu, M. Egashira, "Gas sensing properties of semiconductor heterolayer sensors fabricated by slide-off transfer printing", Sens. Actua. B, 77 (2001) 41-47.

[43] F. Parret, Ph. Ménini, A. Martinez, K. Soulantica, A. Maisonnat, B. Chaudret, "Improvement of micromachined $\mathrm{SnO}_{2}$ gas sensors selectivity by optimized dynamic temperature operating mode”, Sens. Actua. B, 118 (2006) 276-282.

[44] J. Wöllenstein, H. Böttner, M. Jaegle, W.J. Becker, E. Wagner, Material properties and the influence of metallic catalysts at the surface of highly dense $\mathrm{SnO}_{2}$ films, Sens. Actua. $\mathrm{B}, 70$ (2000) 196-202.

[45] E. Zampiceni, E. Bontempi, G. Sberveglieri, L.E. Depero, "Mo influence on $\mathrm{SnO}_{2}$ thin films properties", Thin Solid Films, 418 (2002) 16-20. 
[46] S.T. Navale, G.D. Khuspe, M.A. Chougule, V.B. Patil, Synthesis and characterization of polypyrrole filled with iron oxide nanoparticles. J. Phys. Chem. Solids, 75 (2014) 236.

[47] V.V. Kondalkar, S.S. Mali, N.B. Pawar, R.M. Mane, S. Choudhury, C.K. Hong, P.S. Patil, "Microwave-assisted rapid synthesis of highly porous $\mathrm{TiO}_{2}$ thin films with nanocrystalline framework for efficient photo electrochemical conversion”, Elec. Acta, 143 (2014) 89-97.

[48] O.D. Truong, T.S. Le, H.T. Hao, "Fluoride-free self-template synthesis of hollow $\mathrm{TiO}_{2}$ nanostructures for hydrogen evolution", Cryst. Eng. Comm., 14 (2012) 427.

[49] H. J. Ahn, H.C. Choi, K.W. Park, S.B. Kim, Y.E. Sung, "Investigation of the structural and electrochemical properties of size-controlled SnO2 nanoparticles”, J. Phys. Chem. B, 108 (2004) 9815-9820.

[50] M. Adnane, H. Cachet, G. Folcher, S. Hamzaoui, "Beneficial effects of hydrogen peroxide on growth, structural and electrical properties of sprayed fluorine-doped $\mathrm{SnO}_{2}$ films", Thin Solid Films, 492 (2005) 240-247.

[51] S. T. Navale, G. D. Khuspe, M. A. Chougule, V. B. Patil, Camphor sulfonic acid doped PPy $/ \alpha-\mathrm{Fe}_{2} \mathrm{O}_{3}$ hybrid nanocomposites as $\mathrm{NO}_{2}$ sensors, RSC Adv., 4 (2014) 27998-28004.

[52] S. T. Navale, A. T. Mane, M. A. Chougule, R. D. Sakhare, S. R. Nalage and V. B. Patil, "Highly selective and sensitive room temperature $\mathrm{NO}_{2}$ gas sensor based on Polypyrrole thin films”, Synth. Metal., 189 (2014) 94.

[53] S.T. Navale, M.A. Chougule, V.B. Patil, A.T. Mane, "Highly sensitive, reproducible, selective and stable CSA-polypyrrole $\mathrm{NO}_{2}$ sensor", Synth. Met., 189 (2014) 111-118.

[54] J. Kaur, S.C. Roy, M.C. Bhatnagar, "Effect of indium doped $\mathrm{SnO}_{2}$ nanoparticles on $\mathrm{NO}_{2}$ gas sensing properties”, Sens. Actua. B, 126 (2007) 478-484.

[55] Anjali Sharma, Monika Tomar, Vinay Gupta, " $\mathrm{SnO}_{2}$ thin film sensor with enhanced response for $\mathrm{NO}_{2}$ gas at lower temperatures”, Sens. Actua. B, 156 (2011) 743- 752.

[56] D. K. Bandgar , S.T. Navale, A.T. Mane , S.K. Gupta , D.K. Aswal , V.B. Patil , “Ammonia sensing properties of polyaniline/ $\alpha-\mathrm{Fe}_{2} \mathrm{O}_{3}$ hybrid nanocomposites”, Synth. Met., 204 (2015) $1-9$.

[57] A.T. Mane, S. B. Kulkarni, S. T. Navale, A. A. Ghanwat, N. M. Shinde, JunHo Kim, V. B. Patil, " $\mathrm{NO}_{2}$ sensing properties of nanostructured tungsten oxide thin films", Cera. Inter., 40 (2014) 16495-16502. 


\section{Figure captions:}

Fig. 1. Schematic of thermal evaporation process-mediated $\mathrm{SnO}_{2}$ film formation.

Fig. 2. (a) XRD, (b) XPS survey spectra, (c) core level Sn, and (d) core level O-1s spectrums of $\mathrm{SnO}_{2}$ film.

Fig. 3. (a) SEM, (b) EDAX, (c) 2D, and (d) 3D AFM images of $\mathrm{SnO}_{2}$ film.

Fig. 4. (a) TEM, (b) SAED, and (c) contact angle measurement images of $\mathrm{SnO}_{2}$ film.

Fig. 5. (a) Sensitivity study of $\mathrm{SnO}_{2}$ film towards $100 \mathrm{ppm}$ of various gases, and (b) plot of variation of response of $\mathrm{SnO}_{2}$ sensor with respect to different temperatures.

Fig. 6 (a) Schematic of gas sensing mechanism of $\mathrm{SnO}_{2}$ film with $\mathrm{NO}_{2}$ gas, (b) Plot of change in electrical resistance of $\mathrm{SnO}_{2}$ film upon the interaction of $\mathrm{NO}_{2}$.

Fig. 7. (a) Plots of response as a function of time from 1 to $100 \mathrm{ppm}$ of $\mathrm{NO}_{2}$, (b) dynamic plot of variation of response of $\mathrm{SnO}_{2}$ film sensor to various concentrations of $\mathrm{NO}_{2}$, (c) response repeatability, and (d) stability study of $\mathrm{SnO}_{2}$ sensor film @ $200^{\circ} \mathrm{C}$.

Fig. 8. (a) Impedance spectra of $\mathrm{SnO}_{2}$ film before and after exposure to $\mathrm{NO}_{2} @ 200^{\circ} \mathrm{C}$, (inset shows an equivalent circuit used to interpret the impedance spectroscopy data). 


\section{Table captions:}

Table 1: Standard and observed $2 \theta, d$, and $\left(I / I_{\max }\right)$ values with corresponding hkl plane of $\mathrm{SnO}_{2}$ film.

Table 2: Structural parameters of $\mathrm{SnO}_{2}$ film.

Table 3: Selectivity coefficient $(K)$ values of $\mathrm{SnO}_{2}$ sensor film with $\mathrm{NO}_{2}$ as a target gas.

Table 4: Comparison of different sensing parameters of $\mathrm{SnO}_{2}$ sensor film.

Table 5: Impedance parameters of $\mathrm{SnO}_{2}$ sensor film.

Table 6: Comparison of obtained gas sensing results with those of the reports $\left(\mathrm{NO}_{2}\right.$ entirely) on semiconducting $\mathrm{SnO}_{2}$ and modified $\mathrm{SnO}_{2}$ with suitable catalysts. 


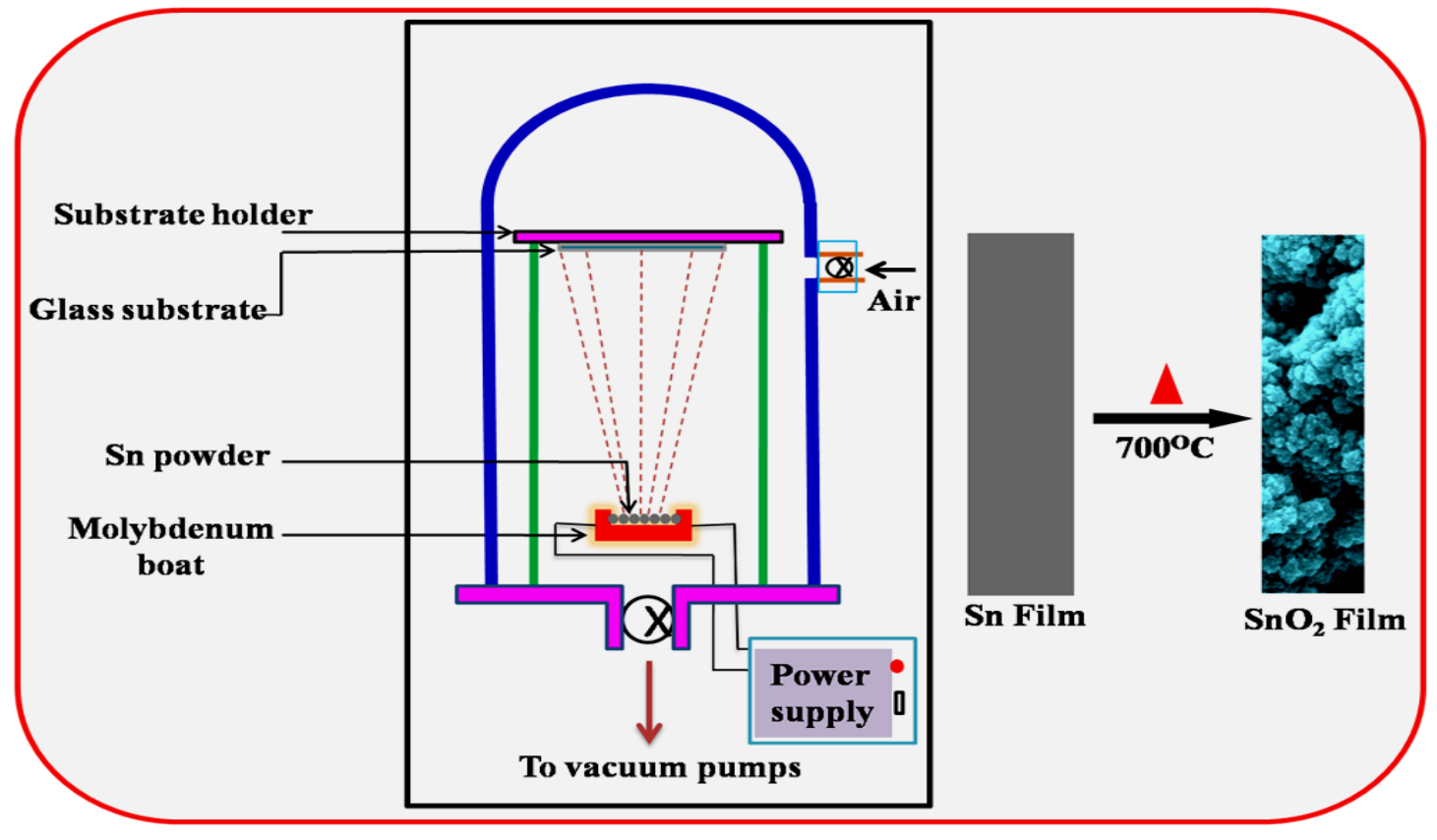

Fig. 1 

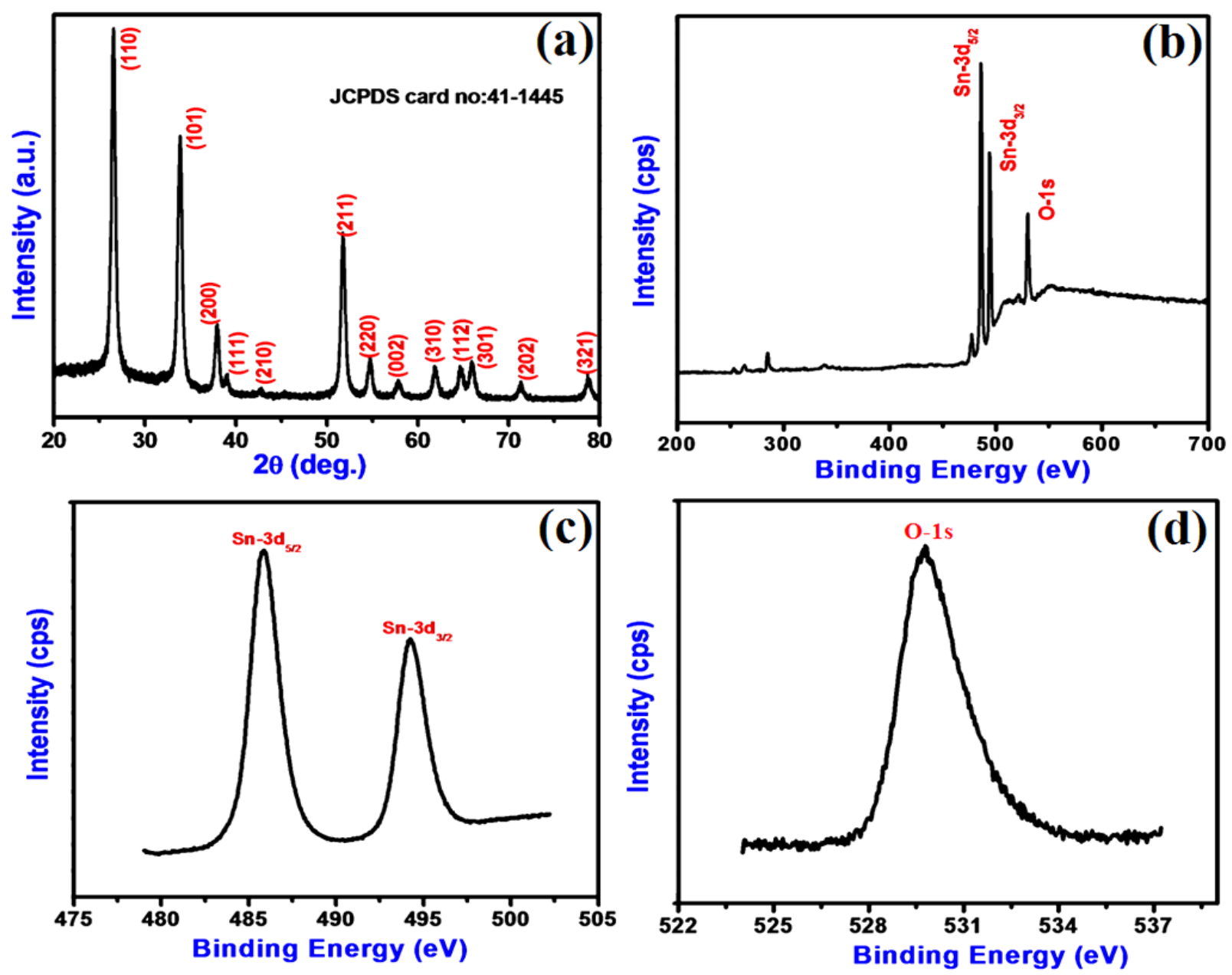

Fig. 2 

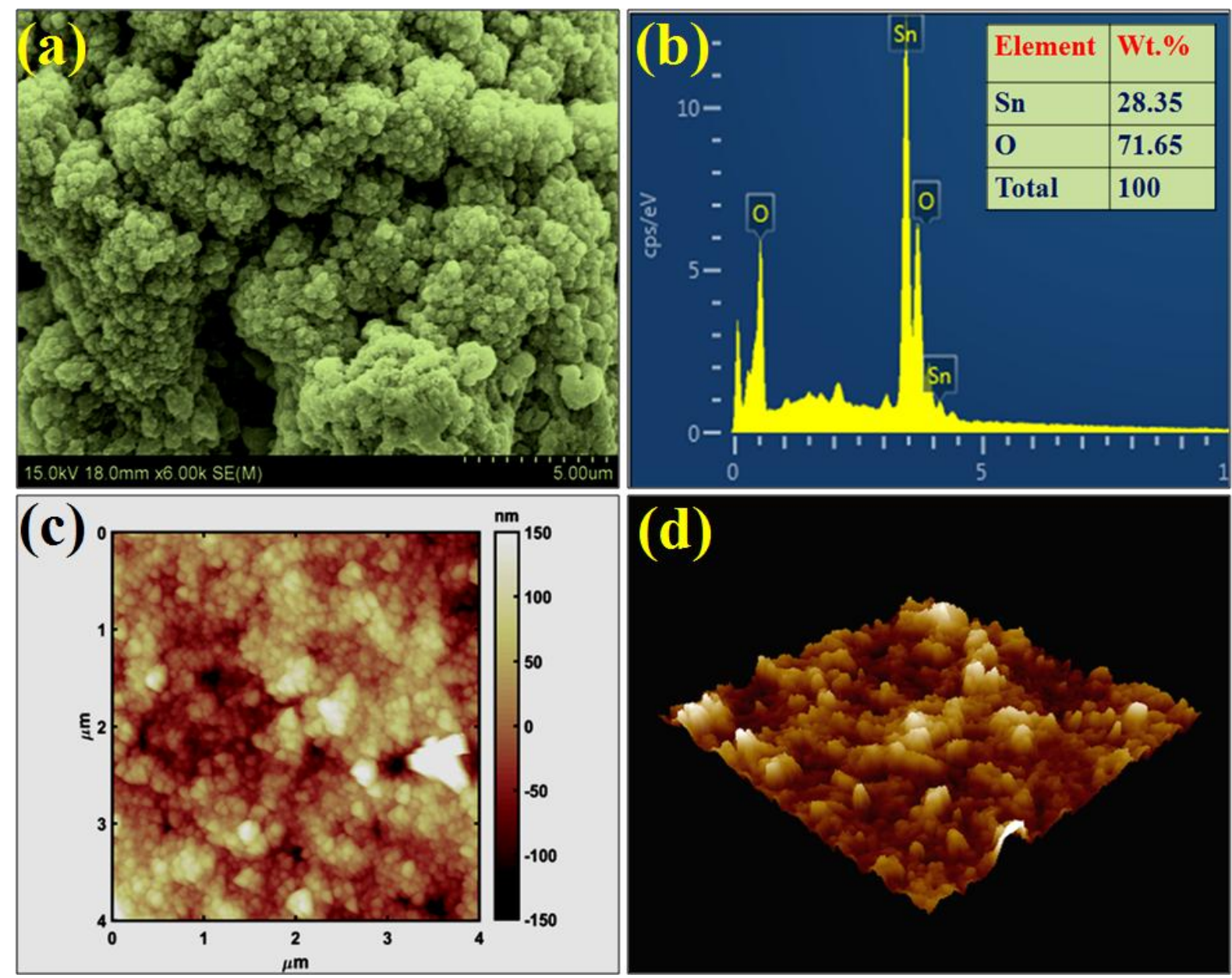

Fig. 3 


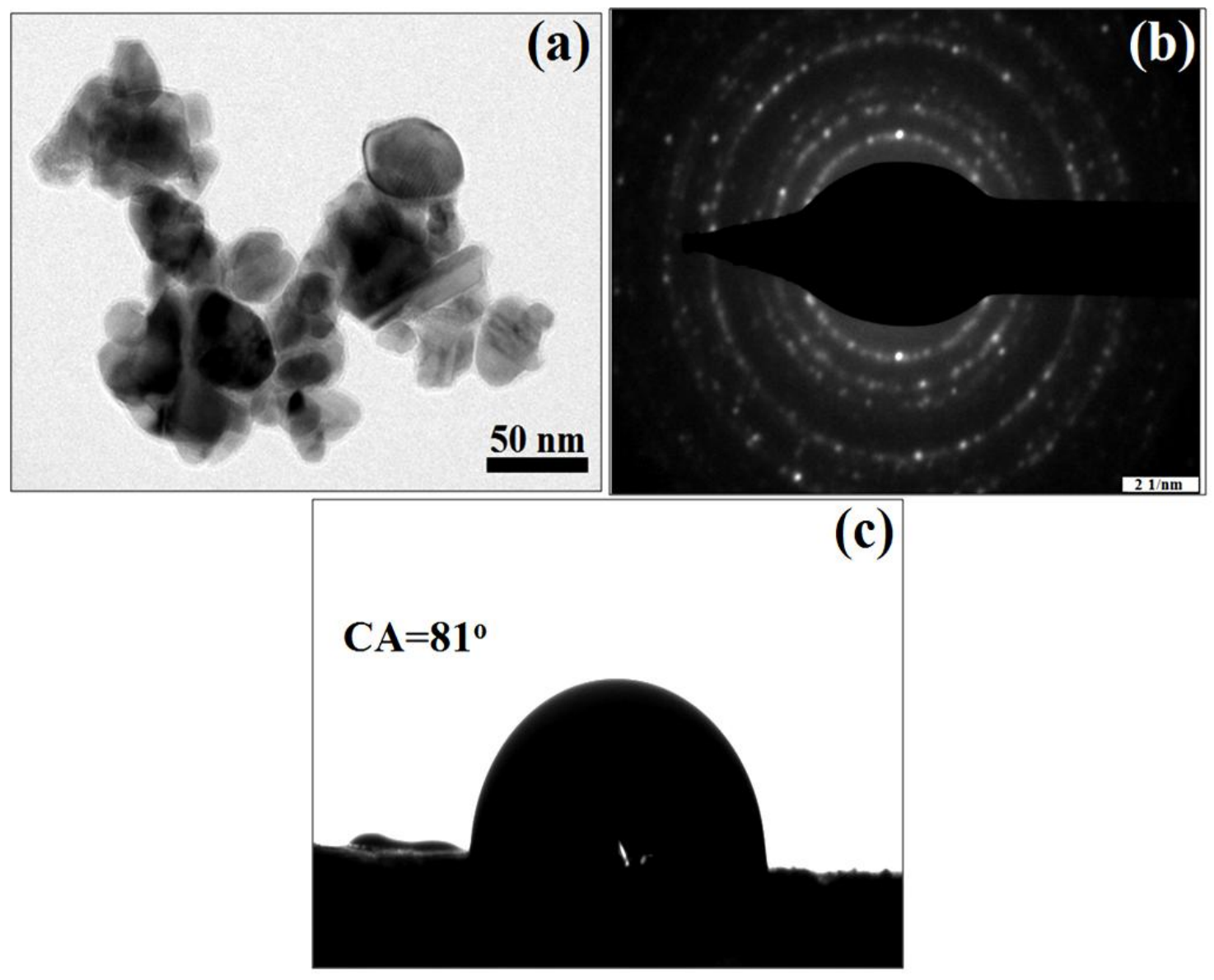

Fig. 4 

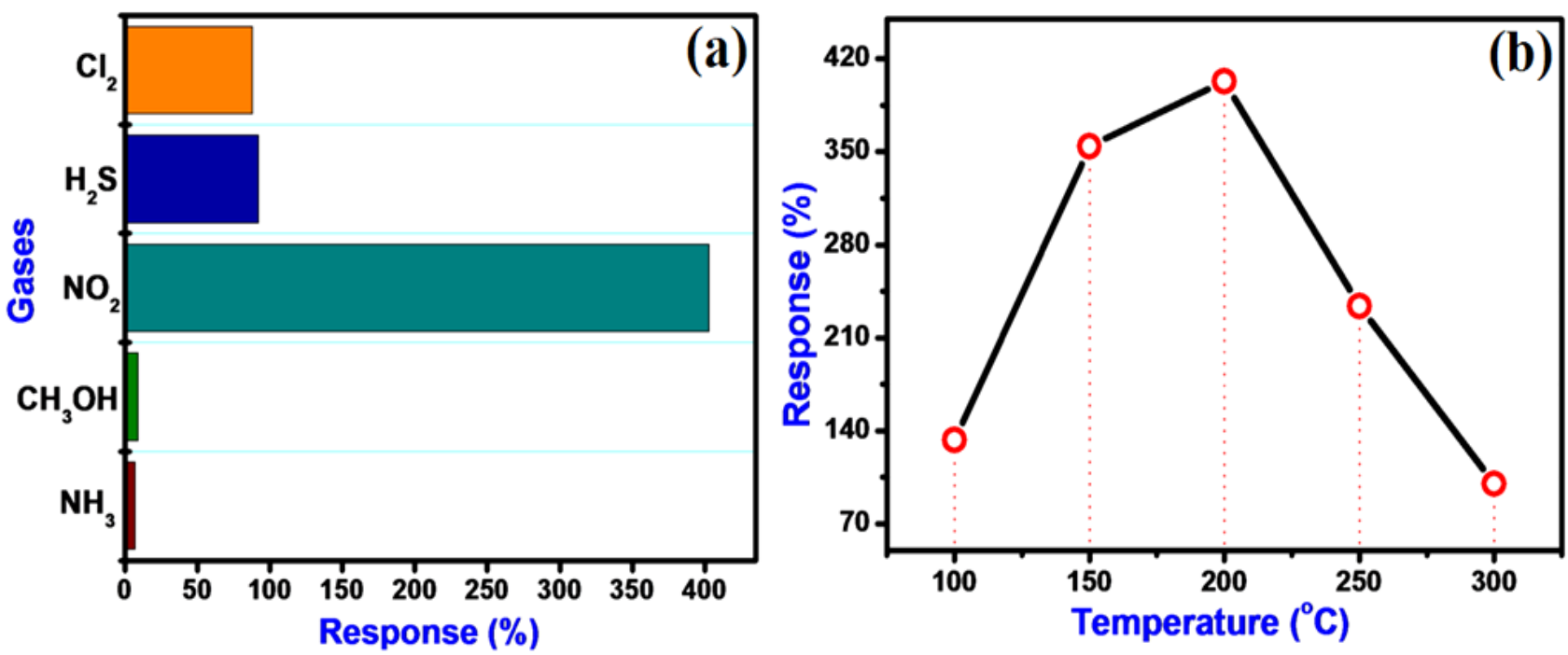

Fig. 5 

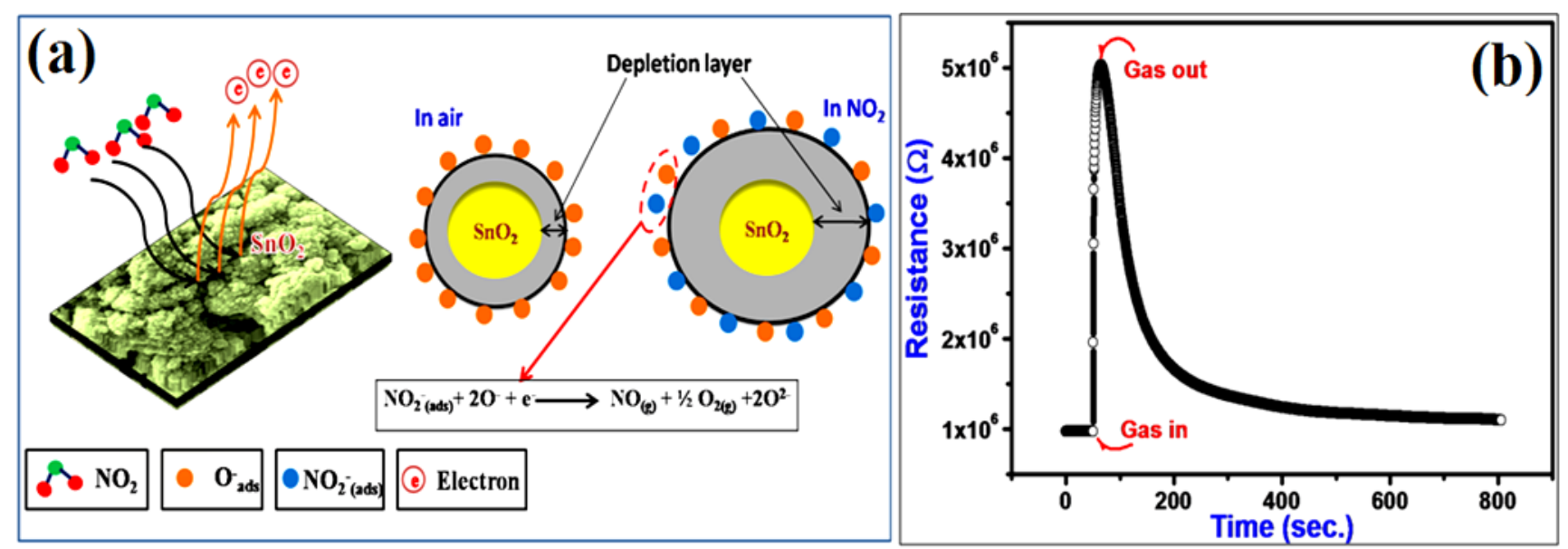

Fig. 6 

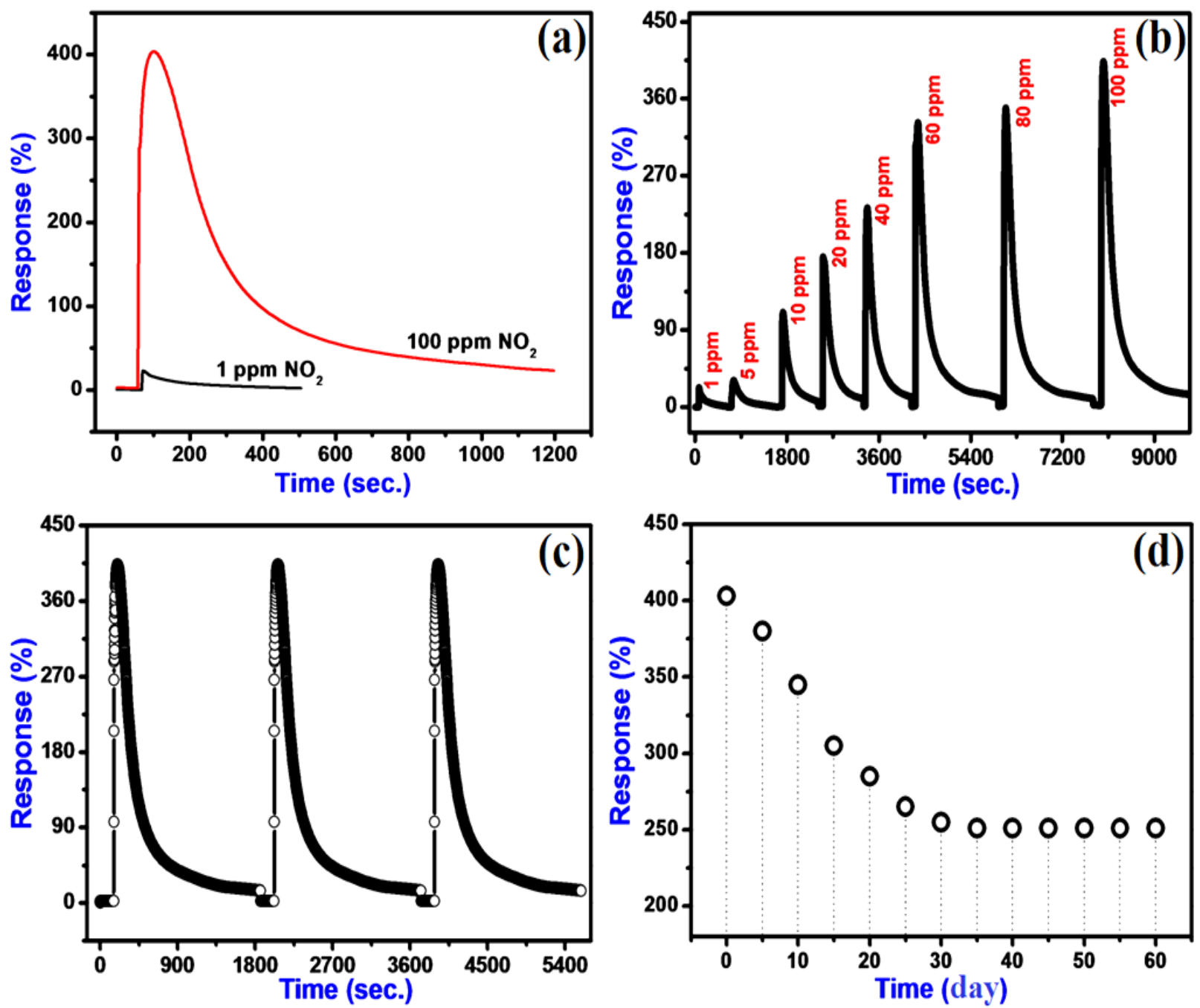

Fig. 7 


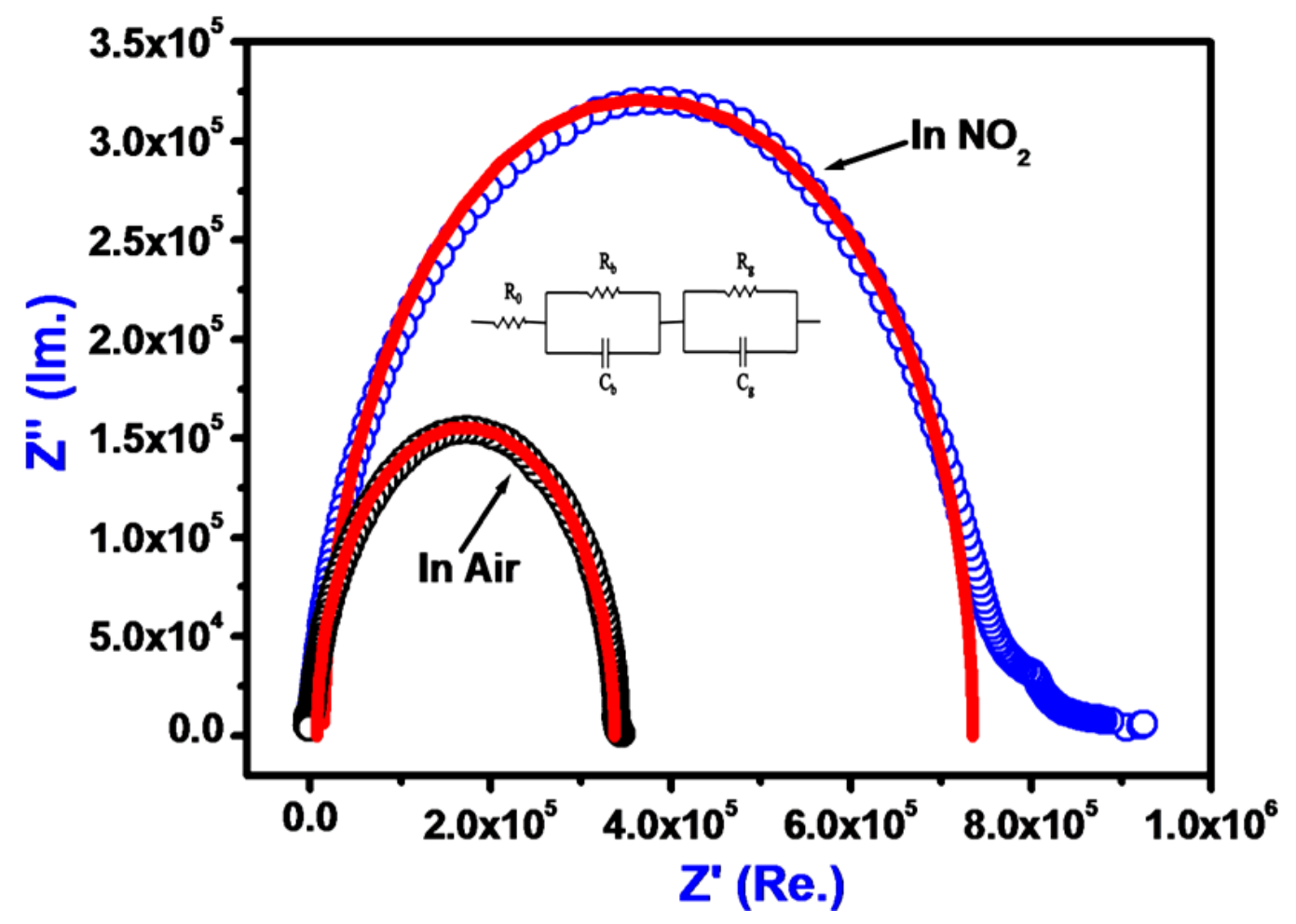

Fig. 8 
Table 1

\begin{tabular}{ccccccc}
\hline \multirow{2}{*}{$2 \theta\left(^{\circ}\right)$} & \multicolumn{2}{c}{$d(\AA)$} & \multicolumn{2}{c}{$I / I_{\max }(\%)$} & hkl \\
\cline { 3 - 5 } Standard & Observed & Standard & Observed & Standard & Observed & \\
\hline 26.61 & 26.60 & 3.3474 & 3.3488 & 92 & 100 & $(110)$ \\
33.89 & 33.85 & 2.6430 & 2.6463 & 88 & 73.08 & $(101)$ \\
37.94 & 37.98 & 2.3693 & 2.3675 & 27 & 22.24 & $(200)$ \\
38.96 & 39.00 & 2.3097 & 2.3079 & 5 & 7.98 & $(111)$ \\
42.63 & 24.77 & 2.1192 & 3.5919 & 1 & 4.01 & $(210)$ \\
51.78 & 51.87 & 1.7643 & 1.7615 & 100 & 46.58 & $(211)$ \\
54.65 & 54.7 & 1.6780 & 1.6768 & 26 & 12.25 & $(220)$ \\
57.81 & 57.82 & 1.5936 & 1.5935 & 12 & 6 & $(002)$ \\
61.87 & 61.99 & 1.4986 & 1.4960 & 23 & 9.98 & $(310)$ \\
64.71 & 64.68 & 1.4394 & 1.4401 & 26 & 9.95 & $(112)$ \\
65.93 & 65.99 & 1.4157 & 1.4147 & 31 & 11.38 & $(301)$ \\
71.27 & 71.27 & 1.3222 & 1.3223 & 14 & 5.01 & $(202)$ \\
78.71 & 78.72 & 1.2148 & 1.2147 & 23 & 6.84 & $(321)$ \\
\hline
\end{tabular}


Table 2

\begin{tabular}{cccc}
\hline $\begin{array}{c}\text { Crystallite size } \\
(\mathrm{nm})\end{array}$ & Micro-strain & $\begin{array}{c}\text { dislocation density } \\
\left(\mathrm{cm}^{-2}\right)\end{array}$ & Stacking fault \\
\hline 30 & 0.114 & 0.001 & 0.5207 \\
\hline
\end{tabular}


Table 3

\begin{tabular}{ccccc}
\hline Gas & $\mathrm{H}_{2} \mathrm{~S}$ & $\mathrm{Cl}_{2}$ & $\mathrm{CH}_{3} \mathrm{OH}$ & $\mathrm{NH}_{3}$ \\
\hline 'K' value & 4.38 & 4.57 & 44.77 & 57.57 \\
\hline
\end{tabular}


Table 4

\begin{tabular}{|c|c|c|c|c|c|}
\hline Sample & $\begin{array}{l}\text { Operating } \\
\text { Temp. }\end{array}$ & \begin{tabular}{c}
\multicolumn{2}{c}{ Conc. of } \\
$\mathrm{NO}_{2}$ gas (ppm)
\end{tabular} & Response (\%) & $\begin{array}{c}\text { Response time } \\
\text { (s) }\end{array}$ & $\begin{array}{c}\text { Recovery } \\
\text { time (s) }\end{array}$ \\
\hline \multirow{8}{*}{$\mathrm{SnO}_{2}$} & \multirow{8}{*}{$200^{\circ} \mathrm{C}$} & 1 & 23 & 10 & 123 \\
\hline & & 5 & 31 & 9.0 & 135 \\
\hline & & 10 & 112 & 8.7 & 144 \\
\hline & & 20 & 176 & 8.0 & 153 \\
\hline & & 40 & 234 & 7.6 & 160 \\
\hline & & 60 & 336 & 6.4 & 172 \\
\hline & & 80 & 352 & 5.0 & 180 \\
\hline & & 100 & 403 & 4.0 & 210 \\
\hline
\end{tabular}


Table 5

\begin{tabular}{cccccc}
\hline $\begin{array}{c}\text { Parameters } \\
\longrightarrow\end{array}$ & $\begin{array}{c}\mathrm{R}_{\mathrm{o}} \\
(\mathrm{k} \Omega)\end{array}$ & $\begin{array}{c}\mathrm{C}_{\mathrm{b}} \\
(\mathrm{nF})\end{array}$ & $\begin{array}{c}\mathrm{R}_{\mathrm{b}} \\
(\mathrm{M} \Omega)\end{array}$ & $\begin{array}{c}\mathrm{C}_{\mathrm{g}} \\
(\mathrm{nF})\end{array}$ & $\begin{array}{c}\mathrm{R}_{\mathrm{g}} \\
(\mathrm{M} \Omega)\end{array}$ \\
\hline Unexposed (In air) & 7 & 155.8 & 0.16 & 75 & 166547 \\
\hline Exposed to 100ppm $\mathrm{NO}_{2}$ & 7 & 75.7 & 0.38 & 1.01 & 334436 \\
\hline
\end{tabular}


Table 6

\begin{tabular}{|c|c|c|c|c|c|c|}
\hline Material & Synthesis route & Catalyst/modifier & $\begin{array}{c}\text { Sensing } \\
\text { Temp. } \\
\left({ }^{\circ} \mathrm{c}\right)\end{array}$ & $\begin{array}{c}\text { Response } \\
\text { value } \\
\text { [conc.] } \\
\end{array}$ & $\begin{array}{c}\text { Respone / } \\
\text { Recovey } \\
\text { time }\end{array}$ & Ref. \\
\hline $\mathrm{SnO}_{2}$ thin film & Sol-gel & $\mathrm{SnO}_{2}$ & 250 & $40[5 \mathrm{ppm}]$ & $80 \mathrm{~s} / 1 \mathrm{~h}$ & {$[35]$} \\
\hline $\begin{array}{l}\mathrm{SnO}_{2} \text { nano- } \\
\text { composite }\end{array}$ & $\begin{array}{c}\text { Reverse micro } \\
\text { emulsion }\end{array}$ & $\mathrm{ZnO}$ & 250 & 34 [500 ppm] & - & {$[36]$} \\
\hline $\begin{array}{c}\mathrm{SnO}_{2} \text { pellete } \\
\text { hetrojunction }\end{array}$ & $\begin{array}{l}\text { Powder mixing } \\
\text { (ball milling) }\end{array}$ & $\mathrm{WO}_{3}$ & 300 & $6.5[5 \mathrm{ppm}]$ & - & {$[37]$} \\
\hline $\begin{array}{c}\mathrm{SnO}_{2} \\
\text { nanoparticles }\end{array}$ & RF sputtering & MWCNTs & 300 & $\begin{array}{c}5.35 \\
{[1.2 \mathrm{ppm}]}\end{array}$ & $50 \mathrm{~s} / 100 \mathrm{~s}$ & {$[38]$} \\
\hline $\mathrm{SnO}_{2}$ thin film & $\begin{array}{l}\text { Rheotaxial } \\
\text { growth } \\
\text { (Ar Gas) }\end{array}$ & $\mathrm{WO}_{3}$ & 300 & $40[10 \mathrm{ppm}]$ & $\underset{\min }{10 \mathrm{~min} / 15}$ & [39] \\
\hline $\begin{array}{l}\mathrm{SnO}_{2} \text { thick } \\
\text { film }\end{array}$ & Screen printing & $\mathrm{WO}_{3}-\mathrm{Au}$ & - & $1[10 \mathrm{ppm}]$ & $2 \mathrm{~min} / 3 \mathrm{~min}$ & [40] \\
\hline $\mathrm{SnO}_{2}$ thin film & Screen printing & $\mathrm{WO}_{3}$ & 200 & $400[200 \mathrm{ppm}]$ & - & {$[41]$} \\
\hline $\mathrm{SnO}_{2}$ thin film & $\begin{array}{l}\text { Slide of transfer } \\
\text { printing }\end{array}$ & $\mathrm{WO}_{3}$ & 400 & 8 [100 ppm] & $20 \mathrm{~s} / 80 \mathrm{~s}$ & {$[42]$} \\
\hline $\begin{array}{c}\mathrm{SnO}_{2} \\
\text { nanomaterials }\end{array}$ & Chemical route & $\mathrm{Pd}$ & 300 & $0.1[200 \mathrm{ppm}]$ & $0.2 \mathrm{~s} / 1 \mathrm{~s}$ & {$[43]$} \\
\hline $\mathrm{SnO}_{2}$ thin film & sputtering & $\mathrm{Pt}$ & 360 & $1[3 \mathrm{ppm}]$ & - & [44] \\
\hline $\mathrm{SnO}_{2}$ thin film & $\begin{array}{l}\text { Sputtering } \\
\text { ( Ar Gas) }\end{array}$ & Mo & 270 & $20[10 \mathrm{ppm}]$ & - & {$[45]$} \\
\hline $\begin{array}{c}\mathrm{SnO}_{2} \\
\text { nanoparticles }\end{array}$ & $\begin{array}{c}\text { Thermal } \\
\text { evaporation } \\
\text { (air) }\end{array}$ & - & 200 & $0.23[1 \mathrm{ppm}]$ & $10 \mathrm{~s} / 123 \mathrm{~s}$ & $\begin{array}{c}\text { Present } \\
\text { work }\end{array}$ \\
\hline
\end{tabular}




\section{Graphical abstract}

Nanostructured Tin Oxide Films: Physical Synthesis,

Characterization, and Gas Sensing Properties

S. M. Ingole, S. T. Navale, Y. H. Navale, D. K. Bandgar, F. J. Stadler, R. S. Mane, N. S.

Ramgir, S. K. Gupta, D. K. Aswal, V.B. Patil*

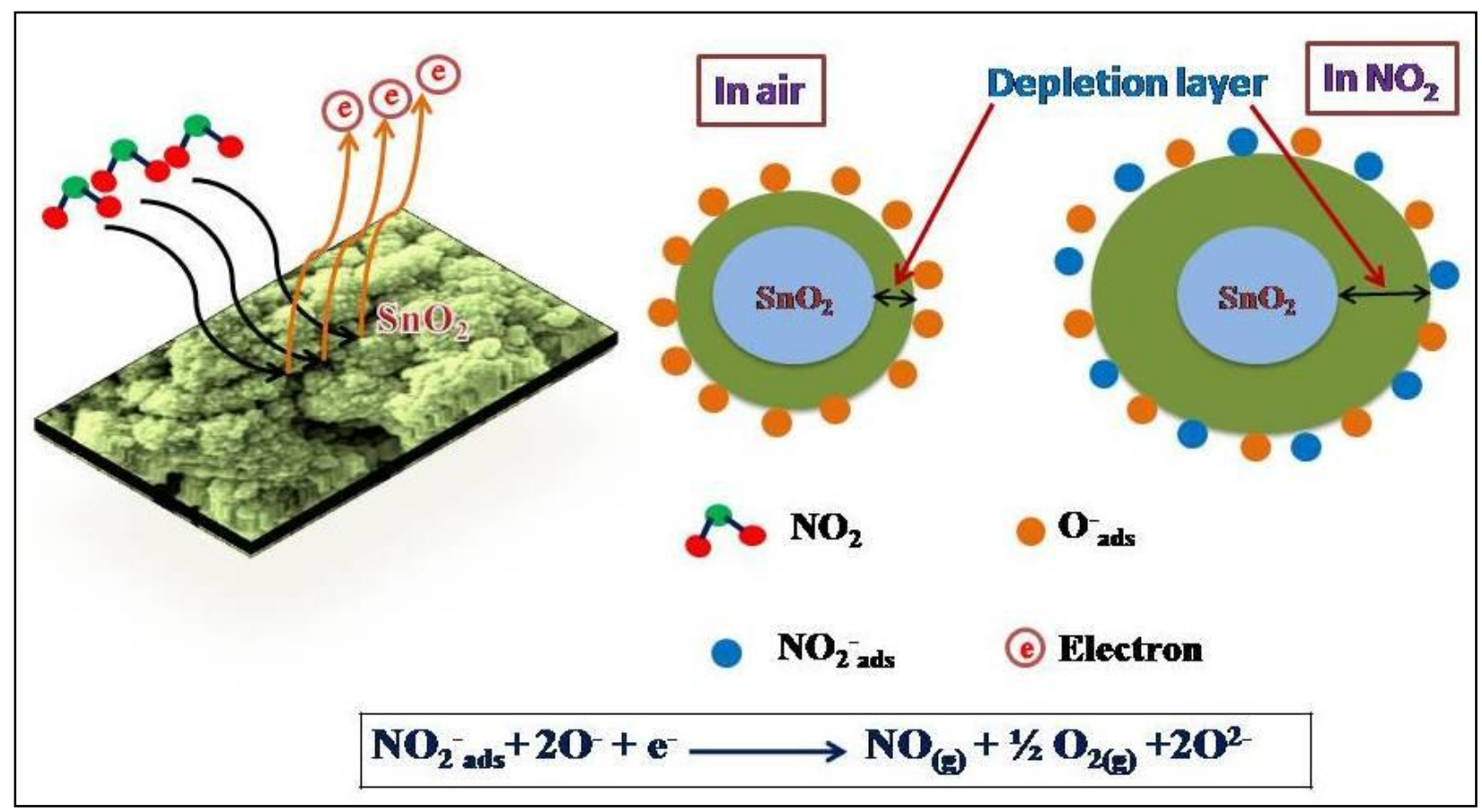

